\title{
A LINGUAGEM DO DIZER E DO DITO EM EMMANUEL LÉVINAS: CONSIDERAÇÕES INTRODUTÓRIAS A DE OUTRO MODO QUE SER
}

\author{
THE LANGUAGE OF THE SAYING AND THE SAID IN EMMANUEL LÉVINAS: \\ INTRODUCTORY CONSIDERATIONS TO OTHERWISE THAN BEING
}

\section{Márcia Bárbara Portella Belian Thiago André Moura de Aquino}

DOI: $\quad 10.20399 / \mathrm{P} 1982-999 X .2015 v 1 n 2 p p 18-33$

\begin{abstract}
RESUMO: Este artigo buscou trazer algumas considerações introdutórias a De Outro Modo que Ser, partindo do diálogo entre Derrida e Lévinas em relação à questão da linguagem ontológica. Vimos que a resposta de Lévinas a Derrida aponta par de conceitos Dizer e Dito, cuja relação marca que o pensamento de Lévinas não é de rejeição do ser, mas de um redirecionamento deste para o sentido da responsabilidade.
\end{abstract}

PALAVRAS-CHAVES: Lévinas - De Outro Modo que Ser - Totalidade e Infinito Dizer - Dito - linguagem

ABSTRACT: This paper sought to bring some introductory considerations to Otherwise than Being, starting from the dialogue between Derrida and Lévinas with regard to the question of the ontological language. We have seen that the Lévinas' answer to Derrida points out the pair of concepts Saying and Said, whose relation marks that the Lévinas' thought is not of rejection of being, but of a redirection of this to the sense of responsability.

KEYWORDS: Lévinas - Otherwise than Being - Totality and Infinity - Saying - Said - language

A recepção do pensamento de Emmanuel Lévinas no Brasil se deu inicialmente tomando como obra principal do autor o livro Totalidade e Infinito (2000), de 1961. Recentemente, o livro de 1974, De Outro Modo que Ser (2011), começou a ganhar destaque em nosso país como a segunda obra de grande relevância de Lévinas, de forma que, atualmente, estes dois livros são considerados as duas obras base do pensamento do filósofo. Contudo, a grande diferença de linguagem entre os dois livros traz à tona uma dificuldade para os estudiosos do pensador em relação à abordagem de De Outro Modo que Ser.

A partir disso, o presente artigo objetiva trazer algumas considerações introdutórias a De Outro Modo que Ser para nos situarmos em relação à mudança de linguagem que Lévinas realiza neste livro em relação a Totalidade e Infinito, visando dar uma contribuição em relação a esta problemática. Para isso, abordamos em primeiro 
lugar a crítica realizada por Jacques Derrida em seu texto Violência e Metafísica (1967) e a resposta de Lévinas a Derrida. Em seguida, fizemos um estudo da seção inicial de De Outro Modo que Ser, intitulada O Argumento, como exposição introdutória da argumentação principal do livro.

\section{SOBRE A DIFERENÇA ENTRE TOTALIDADE E INFINITO E DE OUTRO MODO QUE SER}

Em De Outro Modo que Ser, grande parte dos conceitos anteriores de Lévinas passam por uma alteração no sentido de evitar a linguagem ontológica ${ }^{1}$.

Segundo o próprio Lévinas, no Prefácio à Edição Alemã de Totalidade e Infinito:

Autrement qu'être ou au-delà de l'essence já evita a linguagem ontológica - ou, mais exatamente, eidética - à qual Totalité et Infini não cessa de recorrer, para evitar que sua análise, ao questionar o conatus essendi do ser, dê a impressão de repousar sobre o empirismo de uma psicologia (EN, p. 252).

Já em De Deus que vem à Ideia (2008), encontramos a seguinte passagem: “A linguagem ontológica empregada na obra Totalidade e Infinito não é uma linguagem definitiva. Nesta obra, a linguagem é ontológica porque, sobretudo, não quer ser psicológica" (DVI, p. 119).

Entendemos que a escolha pela linguagem ontológica feita por Lévinas em Totalidade e Infinito tinha como objetivo assinalar seu pensamento como filosófico, situado em meio à fenomenologia, também mostrar que ele seguiu determinados procedimentos que segundo ele mesmo "quase técnicas, implementados quase espontaneamente por aqueles que foram formados mesmo que parcialmente, pela obra husserliana" (DEHH, p.135). O seguinte parágrafo, de certa forma, resume o posicionamento de Lévinas em relação à fenomenologia e à filosofia:

\footnotetext{
${ }^{1}$ Geralmente, quando os comentadores se referem à linguagem ontológica, estão falando de um discurso que busca ser mais rigoroso que o da linguagem cotidiana, objetivando dizer o ser das coisas. Para Lévinas, toda linguagem falada e escrita já é ontológica. Quanto ao que chamamos "conceitos" de Lévinas, estes não funcionam como os conceitos da ontologia tradicional, que buscam afirmar o ser das coisas trazendo uma fixidez que seria necessária ao conhecimento. Os conceitos de Lévinas são formados por metáforas. Sugerimos que Lévinas não almejaria uma fixidez de seus conceitos por buscar dizer não o ser, mas o outro do que o ser.
} 
A filosofia não se tornou uma ciência rigorosa, prosseguida por uma equipa de investigadores, conduzindo a resultados definitivos. Muito provavelmente, a filosofia recusa-se a este modo de vida espiritual. Mas algumas de suas esperanças husserlianas encontram-se realizadas. A fenomenologia une os filósofos, sem que isso se processe da forma como o kantismo unia os kantianos ou o espinosismo os espinosistas. Os fenomenólogos não se ligam a teses formalmente enunciadas por Husserl, não se consagram exclusivamente à exegese ou à história dos seus escritos. Há uma certa forma de proceder que os aproxima. Mais do que aderir a um certo número de proposições fixas, eles concordam em abordar as questões de uma certa forma (DEHH, p.135) ${ }^{2}$.

Porém, Lévinas não recorreu à linguagem ontológica em Totalidade e Infinito fazendo uma ontologia nos moldes tradicionais, e sim uma metáfora, que abarca as linguagens ontológica, fenomenológica e religiosa, simbolizando um entrecruzamento entre os pensamentos grego, moderno e judaico. Segundo Pintor-Ramos (2011), a linguagem imperativa da ética, junto com a linguagem filosófica, seria, para Lévinas, o tropo mais adequado para se aproximar da experiência do outro, além da linguagem de Lévinas também fazer um tropo do profetismo escatológico bíblico.

Geralmente assume-se que o que desencadeou a mudança de linguagem de Totalidade e Infinito para De Outro Modo que Ser foram as críticas recebidas da parte de Jacques Derrida em Violência e Metafísica (1967), de que Lévinas ainda faria um ontologismo. Na terceira parte do texto de Derrida, intitulada Diferença e Escatologia, são levantadas algumas questões sobre a linguagem, algumas críticas são contundentes, deixando a argumentação contida em Totalidade e Infinito em uma situação difícil. Citando alguns exemplos, segundo Derrida, Lévinas termina por recorrer em Totalidade e Infinito a categorias que antes havia recusado, usando a conceitualidade tradicional para destruí-la. O exemplo que Derrida nos oferece é o conceito de "exterioridade", que havia sido abandonado por referir-se à espacialidade, mas ao qual Lévinas retorna, inclusive no título do livro em questão: Ensaio sobre a exterioridade. Para Derrida, usando a palavra "exterioridade", Lévinas busca mostrar que a "verdadeira" exterioridade não possui conotação espacial, mas, continuando a crítica, o excesso do infinito é dito na linguagem da totalidade, não há como fugir disto, a metáfora é congênita ao logos, ela é o próprio nascimento da linguagem, que, por sua vez, é a

\footnotetext{
${ }^{2}$ Mais sobre como Lévinas entende a forma de proceder da fenomenologia no texto Reflexões sobre a "Técnica Fenomenológica", publicado originalmente em 1959, apenas dois anos antes de Totalidade e Infinito, e contido no livro Descobrindo a Existência com Husserl e Heidegger.
} 
filosofia, e esta última apenas pode falar, dizer a metáfora, que é sempre pensada no horizonte do Ser. Não é descartando as palavras que se escapa da luz, toda a linguagem já cai na luz do Ser. Simplificando, a crítica direta que entendemos aqui é a de que não haveria como falar de algo que já não pertencesse ao âmbito do Ser.

Uma segunda crítica de Derrida a Lévinas que podemos mencionar é a de que todo discurso seria violento por reter nele o espaço e o Mesmo, fazendo com que a afirmação de Lévinas de que apenas o discurso pode ser justo, que a não-violência seria a essência do discurso, supostamente caia por terra. Derrida sugere que a não-violência seria o telos do discurso e não a sua essência, um telos que seria não-discurso, a paz como um silêncio, um "para além da palavra", um horizonte silencioso da palavra. O discurso daria início à guerra, que, por sua vez, só se encerraria com o fim do discurso. A linguagem, deste modo, só poderia tender à justiça praticando a guerra, usando da violência contra a violência, numa economia da violência que visa evitar a pior violência, que é, justamente, a do silêncio. O filósofo é aquele que escreve envolto em uma guerra da luz, a qual só poderia escapar através da pior violência, a do silêncio.

Em De Outro Modo que Ser, Lévinas faz uma depuração do seu pensamento e da sua linguagem, para torná-los mais voláteis, retirando-os da firmeza do ser. Como a linguagem é, por natureza, ontológica, Lévinas se utiliza do seu método enfático para buscar a linguagem apropriada para dizer além do ser. O método enfático utiliza-se de ênfases e repetições até a exaustão (BECKERT, 2011). Assim Lévinas descreve seu método:

O termo que uso muito neste momento é "ênfase". O método transcendental consiste sempre em buscar o fundamento [...]. A partir daí, uma ideia é justificada quando ela encontrou seu fundamento, quando se mostrou as condições de sua possibilidade. - Por outro lado, na minha forma de proceder que parte do humano [...] há uma outra maneira de justificação de uma ideia pela outra: passar de uma ideia a seu superlativo, até sua ênfase. Eis que uma nova ideia - de forma alguma implicada na primeira - decorre ou emana da ênfase. A nova ideia encontra-se justificada não sobre a base da primeira, mas por sua sublimação [...]. Trato a ênfase como procedimento. Penso encontrar aí a via eminentiae. Em todo caso, é a maneira pela qual passo da responsabilidade à substituição. A ênfase significa ao mesmo tempo figura de retórica, excesso da expressão, maneira de se exagerar e maneira de se mostrar. O termo é muito bom, como o termo "hipérbole": há hipérboles em que as noções se transmudam. Descrever esta mutação também é fazer 
fenomenologia. É a exasperação como método de filosofia (DVI, p. 126-127).

Deste modo, entre muitas alterações por meio da ênfase, a responsabilidade, apresentada em Totalidade e Infinito, torna-se substituição em De Outro Modo que Ser; de igual modo, a relação ética torna-se proximidade; o outro torna-se outro do que o ser, de outro modo que ser, para lá do ser; a submissão torna-se condição de refém; a expressão, o discurso, a palavra original tornam-se o Dizer.

Além do método enfático, Lévinas se utiliza de longos períodos, evitando verbos, num estilo mais exortativo do que argumentativo, fazendo jogos linguísticos e trocadilhos, sem fio condutor e buscando outra lógica (BECKERT, 2011).

Segundo Beckert (2011), os intérpretes de Lévinas se dividem entre a continuidade ou a ruptura entre Totalidade e Infinito e De Outro Modo que Ser. Nosso entendimento é que há uma continuidade entre os dois livros, que os dois livros apresentam a mesma ideia, mas com uma linguagem diferente e com pontos de partida diversos na apresentação, embora o cerne seja o mesmo. De Outro Modo que Ser avança em relação a Totalidade e Infinito na questão da entrada do terceiro e da justiça, para dar conta da ordem do Dito, além de deixar de fora alguns temas de Totalidade e Infinito, como a Seção IV.

A estrutura de De Outro Modo que Ser é semelhante à de Totalidade e Infinito, com a primeira parte espelhando o resto do livro. Para Leora Batnitzky (2007), o argumento de Totalidade e Infinito emerge da própria estrutura do mesmo. Segundo a autora, a primeira seção do livro é diferente das outras três, trazendo o argumento do livro, que será melhor explicitado nas três seções seguintes. No caso de De Outro Modo que Ser, a estrutura é semelhante: o Argumento (capítulo I) espelha a Exposição (capítulos II a V). Segundo Paul Ricoeur, em Outramente (2008), "tudo está dito no texto denominado Argumento". Ricoeur desenvolve o seu texto intitulado Outramente estudando basicamente "O Argumento" e, posteriormente, a parte referente à temática do Terceiro e da Justiça, pois considera que esta "pode ser vista como um avanço, na medida em que ela faz emergir um dito novo suscitado pelo Dizer de outramente que dito" (p. 18).

Em suma, a seção "O Argumento" traz, de forma sucinta, os principais argumentos do livro. Alguns temas parecem responder às críticas de Derrida, como a transcendência como "outro do que o ser" e a ênfase no binômio Dizer e Dito. 
Sugerimos que a principal resposta de Lévinas, que fica implícita no livro, já que ele não cita Derrida expressamente, é a de que Derrida não teria percebido a ambiguidade que existe nos termos "discurso", "linguagem" e "palavra" em Totalidade e Infinito. Tais termos teriam dois significados neste livro: acolhimento do discurso e palavra falada. Esta ambiguidade é resolvida em De Outro Modo que Ser com o binômio Dizer, que significa acolhimento do discurso, relação ética, e Dito, significando palavra falada e consciência; binômio que, aliás, já podemos encontrar, de maneira menos pronunciada, em Totalidade e Infinito. A principal indicação de que Lévinas pretendeu responder a Derrida com o binômio Dizer e Dito é um texto chamado Jacques Derrida Tout Autrement, publicado originalmente na revista L'Arc, número 54, em 1973 (um ano antes de De Outro Modo que Ser) e que encontramos no Noms Propres (2014), onde Lévinas, de fato, responde a Derrida já apontando o binômio Dizer e Dito 3 .

Uma explicação possível sobre a resposta de Lévinas às críticas de Derrida vem como o apontamento da interrupção do Dizer no Dito. O Dizer, em Lévinas, refúgio do subjetivo estruturado a partir do intersubjetivo, não se presta a valores de verdadeiro e falso. Segundo ele, a verdade está no movimento Dito, Desdito e Outramente Dito. Se pensarmos em Totalidade e Infinito como um Dito, Violência e Metafísica de Derrida seria o desdito e De Outro Modo que Ser o outramente dito. A crítica de Derrida se encaixaria na tese de Lévinas de que o Dizer na filosofia se mostra no ceticismo, que viria com Derrida, e na refutação do ceticismo, papel que seria do De Outro Modo que Ser. É para chegar a este outramente dito que serve o método enfático, trazendo novas ideias para falar da mesma coisa. Não haveria como a linguagem de De Outro Modo

\footnotetext{
3 "O que resta construído depois da des-construção é, certamente, a arquitetura severa do discurso que desconstrói e que emprega no presente o verbo ser nas proposições predicativas. Discurso no curso do qual, em pleno abalamento das bases da verdade, contra a evidência do presente vivido que parece oferecer um último refúgio à presença, Derrida tem ainda a força de pronunciar: <<está certo?>>, como se nada pudesse estar em segurança naquele momento e como se segurança ou insegurança devessem ainda importar. [...] Poder-se-ia estar tentado de puxar o argumento deste recurso à linguagem logocêntrica contra esta linguagem mesma, para contestar a des-construção produzida. Via muitas vezes seguida pela refutação do ceticismo, mas onde, primeiramente derrotado e pisado aos pés, o ceticismo se revelava para voltar como filho legítimo da filosofia. [...] Mas seguindo esta via se arriscaria passar ao lado da significação que comporta esta inconsequência mesma. Se passaria ao lado da não simultaneidade incompreensível do Dito e do Dizer, ao lado do deslocamento de sua correlação; deslocamento mínimo, mas tão largo para que ali se trague o discurso cético sem se estrangular pela contradição entre o que significa seu dito e o que significa o fato mesmo de enunciar um dito. [...] A verdade das verdades não seria então terminável em um instante, nem em uma síntese onde se cessa o pretendido movimento da dialética. Ela está no Dito e no Desdito e no Outramente dito [...] Que a linguagem seja transplantada sobre a diferença a mais invisível do tempo, que seu dizer seja deslocado de seu dito, que a correlação não seja rigorosa, (rompendo já a unidade da apercepção e, por consequência, já as possibilidades da experiência), situa certamente a linguagem à parte de todo o empírico que se esgota em presença e em falta de presença. É preciso certamente um dia reencontrar, a partir do Dizer e de sua própria significação, sua correlação com o Dito - e esta não é impossível” (NP, p. 89-93, tradução nossa).
} 
que Ser deixar de ser ontológica, já que, para Lévinas, qualquer linguagem falada ou escrita, ou até mesmo o que se passa em nossa consciência, é já ontologia. Ele assume que toda a linguagem do Dito está já no âmbito do ser, o Dizer é a interrupção, portanto, não haveria como De Outro Modo que Ser deixar de fazer uma metáfora e de fato "atingir" o de outro modo que ser, já que o outro do que o ser só chega à consciência como interrupção, sem qualquer conteúdo representacional. A interrupção é o único ponto de contato entre o outro do que o ser e a consciência, o ser. É este ponto de contato que justifica a pertinência de se tentar falar do outro do que o ser e a possibilidade de se falar deste. Contudo, o dito sobre o outro do que o ser é sempre uma traição, uma reversão do sentido para-o-Outro, um modo de falar impróprio. A questão é que não se pode falar o que é o outro do que o ser, mas, já que sabemos qual é o evento que traz o outro do que o ser à nossa consciência, é possível remeter a esse "mistério" falando do próprio evento de contato com o outro do que o ser, que é a relação ética, e é isso que Lévinas faz, descreve a relação ética, utilizando-se de metáforas que, supostamente, fariam o "esforço" de falar o outro do que o ser por meio da relação que o ser estabelece com este. Com isso, De Outro Modo que Ser faz uma nova metáfora derivada do método enfático, basta, para exemplificarmos isto, citarmos termos centrais como "proximidade", "substituição" e "Dizer". Também há, como já havíamos afirmado, uma tentativa de evitar o verbo ser e a procura de outra lógica, essas duas partes também são metáforas por si mesmas, pois não se sairia da luz do ser evitando o verbo ser, nem procurando outra lógica, pois toda lógica já pertence ao âmbito do ser. Contudo, esta nova metáfora parece querer indicar que o problema de Totalidade e Infinito não estaria em sua linguagem, já que é possível falar da mesma coisa e do mesmo evento através de outra linguagem, em outras palavras, não se confrontaria as teses de Totalidade e Infinito pela análise da linguagem utilizada, pois outra linguagem serviria para dizer as mesmas teses.

\section{ESTUDO DA SEÇÃO “O ARGUMENTO” DE DE OUTRO MODO QUE SER}

Lévinas começa o livro De Outro Modo que Ser dizendo que transcender significa passar ao outro do que o ser, ao para lá da essência, ao de outro modo que ser. O outro do que o ser é a ênfase do Outro. Em Totalidade e Infinito, a ligação que percebemos entre o Outro e o outro homem é praticamente imediata. Já o termo "outro 
do que o ser" procura escapar da referência ao ser afastando-se um pouco da referência ao outro homem.

O outro do que o ser seria o oposto do ser, o qual, segundo Lévinas, Platão teria deixado de tratar no Sofista, mas que teria tratado na República (com a ideia de Bem para além do ser). "Passar" não é ir ao nada, o outro do que o ser não é o nada. Não existe oposição entre o ser e o nada. A negatividade que procura rejeitar o ser desenvolve com ele uma dialética especulativa que pertence ainda ao âmbito do ser. $\mathrm{O}$ há (il y $a$ ) preenche de imediato o vazio desta negatividade e o ser termina por dominar o não-ser. Isto significa dizer que a consciência nunca é invadida pelo nada, o há (il y $a$ ), uma dimensão mítica, como trabalhado em Totalidade e Infinito, imediatamente ocupa o vazio que a negatividade tenta formar, fazendo o não-ser já fazer referência e pertencer ainda ao âmbito do ser. A consciência só pode sair do âmbito do ser através do contato com o outro do que o ser. O ser estabelece uma comunidade de destino entre os incomparáveis, colocando-os em conjunção por analogia, conjuntura esta que termina por ser sublinhada quando se tenta dissolvê-la, quando se nega o ser, como já foi dito, o há imediatamente ocupa o vazio deixado.

Para Lévinas, não é em ser ou não-ser que se encontra a questão da transcendência, mas em uma diferença para além destes, que é o outro do que o ser. Transcender é "passar" ao outro do que o ser. Esta diferença também não é um mundo oculto, como uma cidade celeste. Na transcendência, não se passa para um outro mundo que está nos bastidores, nem se imerge em uma totalidade por um processo consciente de negação da individuação, mas, através da modalidade da Ileidade, um modo de ambiguidade, tem-se, como explica Thomas (2004), a dissolução das margens da individuação ao mesmo tempo em que o Eu único é afirmado. O outro do que o ser é a transcendência em relação ao ser, a interrupção realizada pelo que não é o Eu.

Essência é persistência no ser, interessamento, que não é apenas refutar a negatividade, mas é também conatus. O conatus é o modo positivo do interessamento. O pensamento de uma guerra, sincronismo extremo das essências, de todos contra todos se funda nesta persistência no ser. Na modernidade, a razão foi utilizada para frear o choque imediato entre os seres, o que Lévinas denomina "paz fundada na razão". Por meio do cálculo, da paciência, da mediação, da política, a guerra foi substituída pelo comércio e pela troca, sincronia do interessamento. A promessa de compensação futura é o que mantém o conatus paciente, mas é o que termina por gerar rumores sobre a ausência de fundamentos divinos vindos do céu para os homens (morte de Deus), 
porque, mesmo que se coloque as compensações em um futuro distante, o mau estabelecimento ou a deturpação do compromisso, invertendo a relação recompensa e castigo para as virtudes e vícios, respectivamente, valida os referidos rumores. A paz na razão termina, segundo o autor, sucumbindo aos interesses. Isto significa que o ser não se limita apenas à consciência, como insistência do il y $a$, mas possui um lado concreto, o conatus. Este é o fundamento da guerra, cujo caminho para a resolução não viria da razão.

Lévinas diz que o ponto é saber se o que separa a essência na paz da essência da guerra é o outro do que o ser, o para lá da essência. Esta frase adianta muita coisa, mas já se pode vislumbrar que a essência na guerra tem uma intrínseca relação com o ser e seu lado concreto, o conatus, e que o outro do que o ser vai ser o ponto fundamental para a essência na paz. A base da procura pela resposta desta questão, de acordo com Lévinas, e base de sustentação do argumento do livro, é o binômio Dizer e Dito, que já aparecem em Totalidade e Infinito, mas de forma muito discreta. Em De Outro Modo que Ser, o Dizer e o Dito são conceitos centrais e emolduram todas as ideias.

Ainda no Argumento, Lévinas fala da influência do Dito sobre o Dizer, que é o encerramento que o ser realiza sobre o outro do que o ser. O Dito é o ser, o conhecimento do ser, a ontologia, a essência, identificada aqui como interessamento, persistência no ser, consciência, e não é um mero jogo verbal ${ }^{4}$. Já o Dizer não é, de forma alguma, um jogo. O Dizer é "pré-original", proximidade, um para o outro, significância da significação, responsabilidade, desinteressamento, substituição, anterior aos signos verbais e aos sistemas linguísticos. Em Totalidade e Infinito, o Dizer corresponderia à própria relação ética, o acolhimento discurso, do rosto, do Outro, e o Dito a chamada relação no Mesmo, ontologia. Em De Outro Modo que Ser, a palavra

\footnotetext{
${ }^{4}$ Em Totalidade e Infinito, Lévinas afirma que a ontologia é a transformação do Outro no Mesmo. No capítulo II de De Outro Modo que Ser, esta transformação é explicada com base no Dito. A consciência realiza a temporalização do tempo, reunindo, pela retenção e pela memória, um conjunto de representações, o âmbito do ser, no qual as coisas recebem uma essência e um significado, são nomeadas e ganham uma identidade. Um sistema de signos é formado, duplicando os seres e as relações, assim como a temporalização é realizada por meio do verbo. A palavra passa a designar "isto enquanto aquilo", mostrando os entes como unidades idênticas, sendo nomeação, denominação, consagração. O Dito fixa, é ontologia. A linguagem do Dito é linguagem ontológica, que fixa as essências e funciona pela lógica formal, é um código. Encontramos o seguinte resumo sobre isto: "A linguagem como Dito pode conceber-se pois como um sistema de nomes que identifica entidades e, assim sendo, como um sistema de signos que duplicam os entes designando as substâncias, os acontecimentos e as relações através de substantivos ou por outras partes do discurso derivadas dos substantivos, designando identidades - em suma, designando. Mas - e com o mesmo direito - a linguagem concebe-se como verbo na proposição predicativa onde as substâncias se desfazem em modos de ser, em modos de temporalização, mas onde a linguagem não duplica o ser dos entes, onde ela expõe a ressonância silenciosa da essência" (DOM, p. $61)$.
} 
mais utilizada para a relação ética é proximidade. Para entendermos a "préoriginalidade" do Dizer, devemos ter em mente que o arché em Lévinas refere-se à arquia da enunciação, ao dito. A pré-originalidade do Dizer não é, em Lévinas, um recurso à anterioridade no sentido ôntico-ontológico, mas sim à proximidade ética imemorável, diacrônica e irrecuperável de um lapso refratário a qualquer sincronização, como nos diz Ricoeur:

Continuemos o trabalho do desdizer. Sem deixar ainda o campo linguístico-ontológico, $[\ldots]$ olhemos atentamente, em primeiro lugar, para o prefixo pré- de 'pré-original'. A querela com as teorias linguísticas que fazem do Dizer um anexo do dito enseja a ocasião de um uso da noção de origem com o qual é mister também romper. A teoria dos atos de discurso e dos performativos e, mesmo mais genericamente, uma linguística da frase como a de Benveniste, sugerem uma posição do sujeito falante, do locutor, como exercendo ato de dizer, como fazendo uso da palavra, portanto, como tomada de iniciativa de discurso. Ora, tal iniciativa leva a fazer do sujeito falante a origem do seu Dizer. Nada disso interessa a Lévinas, na medida em que na 'aproximação' a iniciativa vem principalmente do outro, de outrem. [...] Seja como for, encontramos aí, não importa o preço, a razão da introdução no discurso do pré- de 'pré-original'. Este, por sua vez, carreia o an... de 'an-arquia'. A an-arquia do Dizer ético subtrai-se à arché, à arquia da enunciação, reduzida a uma simples excrescência do dito apofântico. Mas o prefixo pré- não significa anterioridade temporal? [...] Lévinas investe a fundo aqui o tema da proximidade no sentido ético contra o da anterioridade, no sentido ôntico-ontológico. [...] o passado enquanto memorável, isto é, tornado representável pela memória e pela história, depende do tematizável. Daí a qualificação, não somente de pré-original, mas de pré-memorável do Dizer, em ruptura de sincronização. Aqui o prefixo pré- alcança o prefixo dia- se 'dia-crônico' ('a diacronia, refratária a toda sincronização'). Mas, é preciso considerar que esta anterioridade de um passado pré-original e an-árquico não se inscreve por si mesma no tempo sincronizável da memória e da história. É neste sentido que ele é imemorial (RICOEUR, 2008, p. 24-28).

De acordo com Lévinas, em relação ao Dizer, o Dito se assemelha a um jogo. O Dizer torna-se Dito através de uma linguagem que é um sistema linguístico, tema, ontologia, que traduz e ilumina tudo para nós, mas trai o Dizer, subordinando-o ao tema, causando uma reversão no sentido do para-o-outro, mas esta traição, esta reversão de sentido, precisa ser realizada para que a manifestação do de outro modo que ser possa ser expressa, colocada em palavras. 
O Dito significa no Dizer, mas o Dizer mostra-se no Dito. Para isso, o Dizer entra na lógica do Dito, mas sem se esgotar nesta lógica, que já supõe o Dizer, a essência não exclui a responsabilidade, que permanece com a essência, o Dito não faz desaparecer o Dizer, como escreve Lévinas:

O fato de a ex-cepção se mostrar e se tornar verdade no dito não é um pretexto suficiente para erigir em absoluto a peripécia apofântica do Dizer - servil ou angélica.

Peripécia servil ou angélica, ou seja -, mesmo que sublime -, unicamente mediadora. Porque a tematização onde a essência do ser se traduz diante de nós, pois a teoria e o pensamento, seus contemporâneos, não provam uma qualquer falência do Dizer. Eles são motivados pela vocação pré-original do Dizer, pela própria responsabilidade (DOM, p. 28).

Falar que o Dizer se mostra e se torna verdade no Dito não significa afirmar que ele se torna apenas mediador. O Dito é mediador, mas quando o Dizer torna-se Dito, o Dizer não se faz pura mediação. A essência do ser, a teoria, o pensamento, são motivados pelo Dizer, pela responsabilidade, que permanece no Dito. Toda essa exposição quer, em suma, afirmar que a consciência humana e tudo o que esta produz, tudo isto representado pelo termo "Dito", surge em função da responsabilidade com o Outro, do contato com o outro do que o ser, relação ética representada pelo termo "Dizer"5.

Lévinas considera a traição do Dizer realizada pelo Dito um problema metodológico de como reduzir a traição. Para ele, a filosofia tem a tarefa de dizer o Dizer, ou seja, o indizível. O Dizer é indizível por não poder ser recobrado pela consciência. A traição se realiza porque sempre que se enuncia um dito há a inversão do sentido da responsabilidade. O sentido para-o-Outro é a fidelidade (DOM, p. 47), o sentido contrário é traição. Como o Dizer, no Dito, recebe a forma da lógica formal, o Dizer deve ser dito através de uma união de dizer e desdizer, um dizer que se desdiz. Fazer isto é jogar o Dizer, o outro do que o ser, no ser e no não-ser. Esta seria a tarefa da

\footnotetext{
${ }^{5}$ À primeira vista, pode-se entender que a significação do Dizer no Dito é semelhante à distinção entre o que significa o dito, entendido como conteúdo do discurso, e o fato de enunciá-lo. O Dizer no Dito é algo como o impulso de falar, o querer dizer algo a alguém, o fato de voltar-se a outrem para fazê-lo, algo como a motivação da ação de dirigir-se ao outro. Mas o Dizer em sua significação ou dimensão ética, como pura passividade, acolhimento do discurso pré-original, não surge de uma motivação como numa vontade, mas é Desejo despertado na proximidade do um ao outro. Nisto temos a humanidade levinasiana, a impossibilidade ética de passar ao lado do outro.
} 
filosofia, dizer o que não pode ser dito. Devido a isto, Lévinas coloca a seguinte solução "Devemos limitar-nos à situação extrema de um pensamento diacrônico" (DOM, p. 29), que cometeria a traição, mas deixando sempre espaço para que o Dizer ressurja. Na filosofia, o ceticismo é o espaço de ressurgimento do Dizer, a diacronia secreta que sempre retorna à história da filosofia para romper o Dito. Em toda a argumentação sobre o Dizer e o Dito, é possível vislumbrar um diálogo com Derrida. Sugerimos que o que Derrida afirmou sobre o discurso corresponderia ao Dito, à sincronia, à colocação na luz, mas o contato com outro do que o ser se dá por meio do Dizer, da diacronia. A filosofia diria o que não pode ser dito através de um dizer que se desdiz, o que é cumprido pelo binômio ceticismo-refutação do ceticismo. Lévinas entende que buscar, através da filosofia, o fechamento, a conclusão, do discurso seria uma visão "ainda otimista" da filosofia. Para ele, o único fim possível da filosofia é a sua interrupção:

[...] é necessário que o filósofo apague a marca dos seus próprios passos e, sem cessar, as marcas do apagamento das marcas, numa inevitável insistência metodológica. [...] a filosofia suscita um drama entre filósofos e um movimento intersubjectivo que não se assemelha ao diálogo dos membros de uma mesma equipa em ciência, nem mesmo ao diálogo platônico [...] organiza-se como história da filosofia onde entram sempre novos interlocutores que têm que redizer, mas onde os antigos retornam a palavra, para responderem às interpretações que aqueles suscitam (DOM, p. 41).

A essência produz uma ordem, isto é seu próprio destino, mas o anúncio do de outro modo que ser desfaz a ordem produzida por ela. O ser - a essência, a ontologia, o Dito -, já tende à ordem por si mesmo, já o Dizer que irrompe, a responsabilidade, é o que desfaz a ordem e não permite que ela se fixe. De acordo com Lévinas, não é a liberdade que desfaz a ordem produzida pela essência, mas o de outro modo que ser, que é a subjetividade ou a humanidade, "o si-mesmo que rejeita as incorporações da essência" (DOM, p. 30), a minha unicidade não coincide consigo própria.

Segundo Lévinas, o outro do que o ser não está fora do tempo, comandando o tempo a partir de uma ordem eterna, o tempo é essência, mostração desta, "recuperação de todas as distâncias: pela retenção, pela memória e pela história, onde tudo se apresenta ou se representa" (DOM, p. 31). É necessário indicar "um lapso de tempo sem retorno, uma diacronia refratária a toda a sincronização, uma diacronia transcendente" (DOM, p. 31), na temporalização do tempo, que significa o outro do que o ser ou para lá 
da essência, passado pré-original, anárquico, não-representável. É preciso esclarecer o sentido deste lapso de tempo, passado pré-original, não o trazendo à representação, ao presente, fazendo uma relação ontológica, mas mantendo-o em seu passado pré-original, estranho à representação. Isto se faz pensando a temporalização do tempo como Dizer, que tem um poder de equivocação, equívoco ou enigma que é modalidade da transcendência, que escapa ao Dito, à essência, significando para lá "segundo uma significação que hesita entre este para lá e o retorno ao épos da essência" (DOM, p. 31). O equívoco ou enigma do Dizer é a subjetividade, que diz o enigma do Dizer através de um caso concreto, a responsabilidade, na qual se produz uma relação com o passado não recuperável. A responsabilidade é ilimitada e situa-se num passado pré-original, fora da liberdade e da decisão. A subjetividade é um não-lugar que se situa na responsabilidade.

Aquele que responde não está tematizando o diacrônico, que escapa e não pode ser retido, recordado, reconstruído historicamente, contido ou compreendido. "O nãopresente é aqui invisível, separado (santo), e por isso não-origem, anárquico" (DOM, p. 32). Pela sua bondade, o diacrônico não pode ser tematizado, o Bem não pode ser representado, nem depende da liberdade, que é investida pelo Bem, "ninguém é bom voluntariamente" (DOM, p. 32). A impossibilidade de tematização do diacrônico é a de que ele não vem à consciência, não podendo ser retido por esta nem recuperado pela memória. A linguagem sempre expõe o ser, o que vem à consciência, e o diacrônico é justamente aquilo que foge à consciência. O diacrônico é imemorial, irrepresentável, invisível, incomensurável como presente, recusa à conjunção, não totalizável, Infinito. A negatividade do diacrônico torna-se positividade na responsabilidade. $\mathrm{Na}$ responsabilidade ocorre a ordenação a outrem, a substituição, a condição de refém, a significação, o sentido, isto não passa pela escolha. A subjetividade é um sujeito que sofre, que está sujeito, que é traumatizado. A resposta do responsável, ordenação ao rosto do outro, dá-se antes da consciência, antes da liberdade. É como se o invisível deixasse um rastro, o rosto, "enigma, ou ex-cepção do rosto, juiz e parte” (DOM, p. 33). É este rastro na cognição, que é interrupção do Dito, enigma, que torna possível, utilizando-se de metáforas, trazer o diacrônico para o âmbito do Dito. Mesmo sem entendimento, consciência ou liberdade, o responsável dá a sua resposta, ordenação ao rosto do outro. A responsabilidade, em sua positividade, causa uma inversão na ordem do interessamento, as dívidas se multiplicam à medida em que são assumidas. A subjetividade, por um lado, rompe a essência, como ordem no sentido Infinito, antes da consciência, mas, por outro, traz o Infinito à consciência, como enigma, equívoco, 
Dizer. O rastro do outro do que o ser desenha-se e apaga-se no rosto, mostrando-se ambiguamente, como equívoco. Por isso, o Infinito, ou o de outro modo que ser, não pode ser encontrado como se deixasse resíduos. Do rosto, ele desvia, desvio chamado por Lévinas de "Ileidade", um neologismo que deriva do pronome "il" e que significa que o outro, ao invés de ser um "tu", é um "ele", que diz respeito sem entrar em conjunção, não podendo relacionar-se pela consciência, nem ser designado por um tema. Elizabeth Thomas (2004) fala da Ileidade (ou, mas de acordo com o português, Eleidade) como uma significação ética, uma nomeação do modo no qual o sujeito está em relação com o outro do que o ser, ou o Infinito. Ileidade seria diacronia, aquilo que excede, outro lado, para além, ambiguidade do enigma, exposição do sujeito ao Infinito que dissolve a individuação realizada pela consciência, aquilo que expele a subjetividade para fora do ser. É o rastro da Ileidade, que surge à consciência como enigma, como interrupção do próprio movimento da consciência que tendia para a cristalização do Dito, que traz à própria consciência a ideia de um outro do que o ser, que não pode ser retido ou recuperado pela memória.

Segundo Lévinas, o paradoxo da responsabilidade é estar obrigado sem que a obrigação comece em quem está obrigado. A responsabilidade não está na consciência, é anterior a ela, respondendo à ordem que vem não se sabe de onde, antes mesmo que a ordem seja dada. A subjetividade nota o Infinito não pela ordem, mas por desfazer a essência, substituindo-se ao outro, um-para-o-outro, reabsorvendo-se na significação, que, por sua vez, precede a essência. A significação é substituição, subjetividade, Dizer, desinteressamento, separação, proximidade.

A subjetividade, a humanidade, deve ser pensada como terceiro excluído, para além do ser e do não-ser. O terceiro excluído é o outro do que o ser, de outro modo que ser, não-lugar, e todas as nomenclaturas como subjetividade, humanidade, substituição, significação, desinteressamento, anterioridade à essência, para lá da essência, falam dele. O de outro modo que ser rompe a essência, é ética, e é dito pelo Dizer, antes do Dito. A ruptura da essência é subjetividade, suscetibilidade, vulnerabilidade, sensibilidade. A subjetividade é uma "passividade mais passiva que toda a passividade" (DOM, p. 36). Passar ao de outro modo que ser é passividade, sensibilidade levada ao limite. A significância da significação é substituição, sensibilidade. "A substituição no extremo do ser, culmina no Dizer" (DOM, p. 36), Dizer que continua passividade, onde não há vontade, apenas eleição. A ordem do Bem é anterior ao ser. 
Nas categorias ontológicas, segundo Lévinas, a noção de outro é pensada como um obstáculo à inteligibilidade, à liberdade ou à perfeição ou como termo colaborador, como o escravo ou o Deus caridoso, mas a proximidade do outro, do outro do que o ser, não é pensada por categorias ontológicas. A proximidade não deixa de ser diminuição da distância em relação a uma exterioridade, que, em Lévinas, é o outro do que o ser, a alteridade, mas aqui é assinalada pela proximidade do próximo, pela socialidade. "Proximidade como dizer, contacto, sinceridade da exposição; dizer anterior à linguagem, mas sem o qual nenhuma linguagem, como transmissão de mensagens, seria possível" (DOM, p 37). O pensamento de Lévinas não é um pensamento de repúdio ao ser, como uma decadência. É a partir da proximidade que temos o sentido legítimo do ser.

\section{CONSIDERAÇÕES FINAIS}

De Outro Modo que Ser esboça uma resposta às críticas de Derrida, reafirmando e enfatizando as teses já contidas em Totalidade e Infinito e tomando como conceitos centrais o binômio Dizer e Dito. Este par de conceitos é o que permite a Lévinas também superar as críticas de que sua filosofia seria uma tentativa de rejeição ao ser. A relação entre o Dizer e o Dito, mais esmiuçada neste livro, nos permite ver que o âmbito do ser surge na filosofia levinasiana a partir da proximidade, para satisfazer as exigências desta. A questão que se interpõe é a de como reduzir a traição que o Dito realiza em relação ao Dizer. Quando trazido ao sentido legítimo da responsabilidade, o ser desempenhará um papel fundamental no pensamento de Lévinas, a saída da condição de refém instaurada pela proximidade.

\section{REFERÊNCIAS}

BATNITZKY, Leora. Leo Strauss and Emmanuel Levinas: Philosophy and the Politics of Revelation. Cambridge: Cambridge University Press, 2007.

BECKERT, Cristina. Introdução. In: LÉVINAS, Emmanuel. De Outro Modo que Ser ou para lá da Essência. Lisboa: Centro de Filosofia da Universidade de Lisboa, 2011. DERRIDA, Jacques. Violence et Métaphysique: Essai sur la pensée d'Emmanuel Levinas. In: L'Ecriture et Différence. Paris: Éditions du Seuil, 1967.

LÉVINAS, Emmanuel. Autrement qu'Être ou au-Delà de l'Essence. Paris: Le Livre de Poche, 
De Outro Modo que Ser ou para lá da Essência. Lisboa: Centro de Filosofia da Universidade de Lisboa, 2011.

[s.d]. Descobrindo a Existência com Husserl e Heidegger. Lisboa: Instituto Piaget,

. Entre Nós: Ensaios sobre a alteridade. Petrópolis: Vozes, 2010.

Noms Propres. Paris: Fata Morgana, 2014.

Totalidade e Infinito. Lisboa: Edições 70, 2000.

PINTOR-RAMOS, Antonio. Introducción a la edición castellana. In: Emmanuel

Lévinas. De Outro Modo que Ser o más allá de la Esencia. Salamanca: Sígueme, 2011.

PLATÃO. A República. São Paulo: Difusão Europeia do Livro, 1965.

O Sofista. Belém: UFPA, 1980.

RICOEUR, Paul. Outramente: Leitura do livro Autrement qu'être ou au-delà de l'essence de Emmanuel Lévinas. Petrópolis: Vozes, 2008.

THOMAS, Elisabeth. Emmanuel Levinas: Ethics, Justice and the Human beyond Being. Nova York; Londres: 2004. 